\title{
Analysis and Research on the Regional Adaptability of Sponge City
}

\author{
Siwei $\operatorname{Sun}^{1}$ \\ ${ }^{1}$ Department of Environmental Engineering and Technology, Hefei Sikang Institute of Environmental Consulting and Technology, \\ Hefei, 230041, China
}

\begin{abstract}
Based on the three values of per capita water resources, precipitation, and sewage and wastewater discharge, our country's cities are divided into three types: water resource shortage, water quality shortage, and water pollution and water-logging risk cities. Comparing these three kinds of sponge cities, combining with the regional differences of my country's first-tier, new first-tier and second-tier cities, determine the types of sponge cities in my country's important cities. In view of the different water problems of the three types of cities, the regional adaptive construction plan of sponge cities is summarized.
\end{abstract}

\section{Introduction}

In recent years, many cities in my country have suffered from water-logging and water shortage problems. This is because rainwater is not properly discharged and used: urban drainage facilities are backward, and heavy water accumulates during heavy rains, resulting in flood disasters; urban rain and sewage are not diverted and rainwater is not reused, resulting in waste of rainwater. Sponge city is a Chinese expression of urban rainwater management. It refers to a city that is like a sponge and has good "flexibility", achieving a six-in-one diversified model of "seepage, retention, storage, purification, utilization, and drainage". In 2003, the initial concept of my country's sponge city was proposed by Yu Kongjian. He pointed out that "the natural wetlands on both sides of the river are like sponges, regulating the abundance of river water and alleviating drought and flood disasters."

Low-impact development originated from the United States, and was actually applied in Maryland in the 1990s. It uses decentralized, small-scale, low-cost green ecological technology to control storm runoff and pollution, so that the development area is as close to the natural hydrological cycle as possible[1]. In 2014, the British Parliament passed the "Flood and Water Management Act", stipulating that new projects must use a sustainable drainage system, and formulated the "National Standard." Sustainable drainage systems continue to extend the life of drainage systems through methods such as water quality, biodiversity and water resources management.

\section{Regional division of sponge cities}

There is a phenomenon of duplication in domestic sponge cities: if you want to build a sponge city from the root, you need to start with regional adaptability. The regional adaptability analysis of sponge cities in my country is based on the three values of per capita water resources, precipitation, and sewage and wastewater discharge. The cities in my country are divided into three types: water shortage, water quality, and water pollution and waterlogging risk.

\subsection{Current status of my country's water resources}

The total amount of freshwater resources in my country is 2.8 trillion $/ \mathrm{m} 3$, accounting for $6 \%$ of the global freshwater resources, ranking 4 th in the world. However, my country's per capita fresh water consumption is only 2500 $\mathrm{m} 3$, which is $1 / 4$ of the world average level. It is one of the countries with the poorest water resources per capita in the world.

China discharges up to 40 million tons of sewage every day, and 15 of the 27 major domestic rivers have been pollute to various degrees [3]. Our country's GDP water output is 33 yuan $/ \mathrm{m}^{3}$, and developed countries' GDP water output is US\$13-14/ $\mathrm{m}^{3}$. Water prices are generally low [4]. The price of water is not enough to make up for the cost. In southwest, water resources are rich but northern China is short of water resources.

In 2019, the total amount of water resources in the country was 2904.10 billion $/ \mathrm{m}^{3}$, surface water resources were 2799.33 billion $/ \mathrm{m}^{3}$, groundwater resources were 819.15 billion $/ \mathrm{m}^{3}$, and the amount of groundwater and surface water resources was 104.77 billion $/ \mathrm{m}^{3}[5]$. 
In 2018 , domestic water consumption was 87.17 billion $/ \mathrm{m}^{3}$, occupying $14.48 \%$ of total water; industrial water was 121.765 billion $/ \mathrm{m}^{3}$, occupying $20.22 \%$ of total water; agricultural water was 368.23 billion $/ \mathrm{m}^{3}$, occupying $61.16 \%$ of total water; artificial ecological environment supplementing water was 24.96 billion $/ \mathrm{m}^{3}$, occupying the total amount of water is $4.15 \%$ [5].

\subsection{The regional division standard of sponge cities}

\subsubsection{Water-resource type shortage cities}

As water resources cannot meet the city's water demand, large-scale groundwater over-exploitation, lack of inflow of sea water, and long-term river dry-off and other water environment problems in cities are water shortages.

The international water scarcity standard is defined by the Swedish hydrologist Marin Falken mark: a country with a renewable freshwater supply of less than $1700 \mathrm{~m}^{3}$ per person per year means water shortages; less than $1000 \mathrm{~m}^{3}$ per person per year, water resources are extremely scarce[6]. Li Gaoshe divided the annual rainfall of $500-800 \mathrm{~mm}$ into semi-humid areas, and the annual rainfall of $300-500 \mathrm{~mm}$ as semi-arid areas[7]. Therefore, cities with per capita water resources less than $500 \mathrm{~m}^{3}$ per year are extremely water-scarce, and semi-arid areas with annual precipitation less than $400 \mathrm{~mm}$. Within this defined range, regional water resources are scarce and precipitation is small, and it is a water-source type waterscarce city.

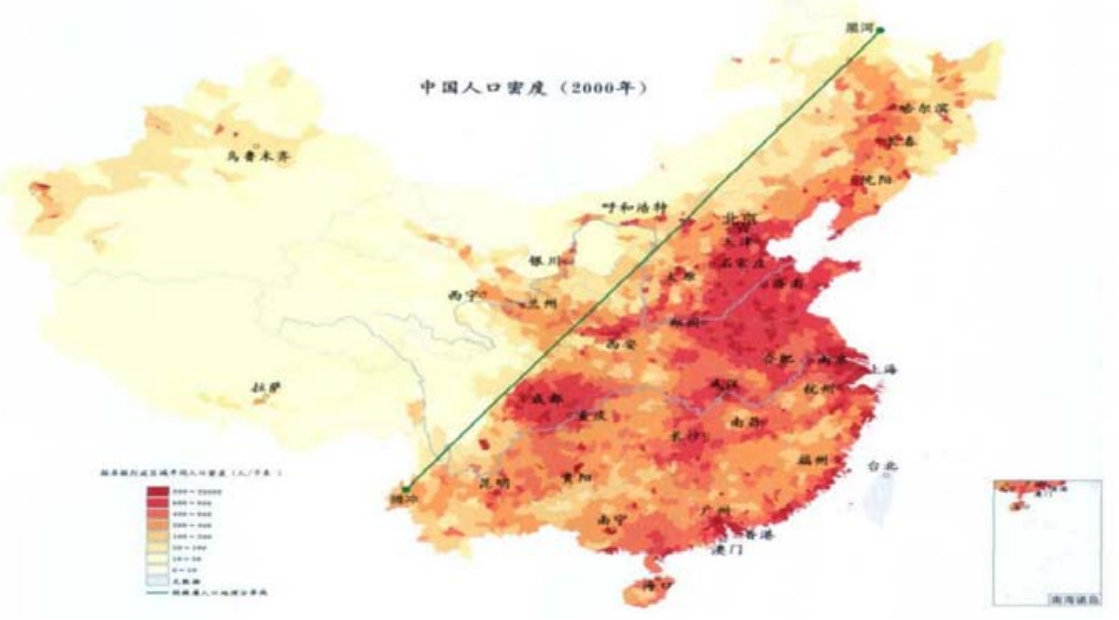

Figure 1. Hu Huanyong Line (2000)

In the 20th century, National Central University $\mathrm{Hu}$ Huanyong proposed the Heihe-Tengchong Line, also known as the Hu Huanyong Line, as shown in Figure 1. The geographical distribution of China's population along the "Aihui-Tengchong" line shows a population distribution pattern that " $36 \%$ of the land in the southeast half supports $96 \%$ of the country's population, and $64 \%$ of the land in the northwest half only supports $4 \%$ of the population" [8]. In addition, the "Hu Huanyong Line" is also the natural boundary of China's social economy, ecological landscape, and meteorological precipitation: it is the boundary between semi-humid areas and semi-arid areas, and the boundary between farming civilization and nomadic civilization. At the same time, this line is also around overlapped to $400 \mathrm{~mm}$ annual precipitation as shown in Figure 2.

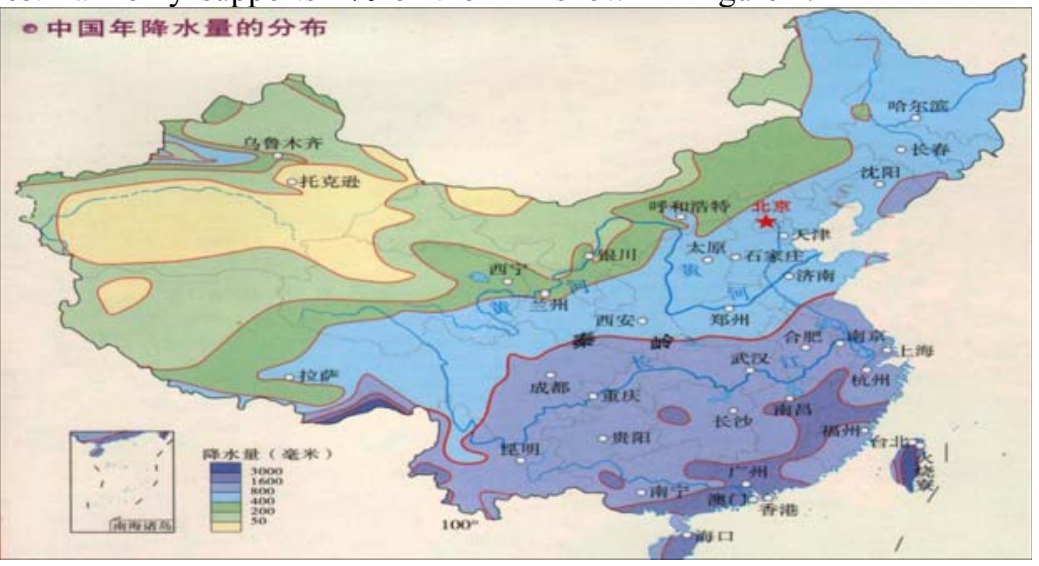

Figure 2. Distribution of annual precipitation in China 
Water source-type scarce water cities are located in the Haihe River Basin, the middle reaches of the Yellow River, the Shandong Peninsula, the middle and lower reaches of the Liaohe River, the northwest and some coastal cities, such as Tianjin, Shijiazhuang, Taiyuan, Yantai, Anshan, Dalian, etc[9]. Northern China is the most severe area. The extraction rate of surface water and groundwater has exceeded the actual capacity of local water resources. However, the supply and demand of water resources are still imbalanced, surface water has basically stopped flowing, and the groundwater level has been declining year by year.

\subsubsection{Water-quality type scarce water cities}

Due to the pollution of the water source, the water quality of the urban water supply is lower than the water use standards of the domestic, industrial, agricultural and other departments, resulting in water shortage, which is a water-quality shortage.

According to international water shortage standards, cities with per capita water resources greater than $500 \mathrm{~m}^{3}$ and less than $1000 \mathrm{~m}^{3}$ are severely water-deficient[6]. In my country's precipitation classification standard, areas with annual precipitation greater than $400 \mathrm{~mm}$ and less than $800 \mathrm{~mm}$ belong to semi-humid areas[7]. Within this defined range, the water resources of cities with a total sewage discharge of more than 40 million tons are in a state of pollution. This part of the city is not because of the low per capita water resources, nor is it that the water system is not abundant, but because of the lack of water caused by the water quality that does not meet the standards due to domestic, industrial, and agricultural pollution.

Water-quality deficient water cities are located in the Changjiang River, Huaihe River, and Pearl River basins: Bengbu, Suzhou, Wuxi, Kunming, Foshan, etc. The Liaohe River, Hailuan River, Huaihe River, and Yellow River basins are seriously polluted, and lakes such as Dianchi Lake, Chaohu Lake, Taihu Lake and Baiyangdian Lake are obviously eutrophication[9].

\subsubsection{Cities at risk of water pollution and water- logging}

According to international water scarcity standards, cities with per capita water resources greater than $1000 \mathrm{~m}^{3}$ and less than $2000 \mathrm{~m}^{3}$ are moderately water-scarce; cities with per capita water resources greater than $2000 \mathrm{~m}^{3}$ and less than $3000 \mathrm{~m} 3$ are mildly water-scarce[6]. In my country's precipitation classification standards, the annual precipitation is greater than $800 \mathrm{~mm}$ as humid areas [7]. The $800 \mathrm{~mm}$ iso-precipitation line of my country's annual precipitation coincides with the Qinling-Huaihe line, which is the north-south boundary of China's geography. Within this defined range, the water resources of cities with a total sewage discharge of more than 40 million tons are in a state of pollution. This part of the city has heavy rainfall and serious pollution with water pollution and water-logging risk.

Reasons for water pollution and water-logging risk cities:

(1) Our country's urban development model is "on the ground first, then underground", which has caused the contradiction between the rapid urban development and the urban water-logging prevention system. The backward construction of urban drainage and flood discharge facilities is accompanied by problems such as blockage and aging of pipelines.

(2) Our country has developed a lot of wasteland in the process of urbanization, reducing permeable green land and increasing hardened land. The reduced water seepage capacity leads to rapid accumulation of rainwater, resulting in serious urban water-logging. Rainwater coerces urban pollutants and forms water pollution.

(3) Our country's developers tend to construct projects in low-level areas. This area is easy to be partially submerged in the rainstorm season. With the convenience of later demolition and the government's "land finance" support, developers can quickly obtain huge profits.

\section{Types of cities in my country-based on the regional classification standard of sponge cities}

Comparing the above three kinds of sponge cities' regional classification standards, and combining the characteristics of regional differences in my country's first-tier, new first-tier and second-tier cities[10], determine the types of sponge cities in my country's important cities.

Tier 1 cities: Beijing, Shanghai, Guangzhou, Shenzhen.

New first-tier cities: Chengdu, Hangzhou, Wuhan, Tianjin, Nanjing, Chongqing, Xi'an, Changsha, Qingdao, Shenyang, Suzhou, Zhengzhou, Dongguan, Hefei, Foshan.

Second-tier cities: Ningbo, Kunming, Fuzhou, Wuxi, Xiamen, Jinan, Dalian, Harbin, Wenzhou, Shijiazhuang, Quanzhou, Nanning, Changchun, Nanchang, Guiyang, Jinhua, Changzhou, Huizhou, Jiaxing, Nantong, Xuzhou, Taiyuan, Zhuhai, Zhongshan, Baoding, Lanzhou, Taizhou, Shaoxing, Yantai, Langfang.

Table 1. Regional Classification of Sponge cities in my country's Important Cities (2019)[11]

\begin{tabular}{|c|c|c|c|c|c|c|c|}
\hline NO. & city & classification & $\begin{array}{c}\text { Water } \\
\text { resources } \\
\text { per capita } \\
/ \mathbf{m}^{\mathbf{3}}\end{array}$ & $\begin{array}{c}\text { Water } \\
\text { consumptio } \\
\mathbf{n} \text { per capita } \\
/ \mathbf{m}^{3}\end{array}$ & $\begin{array}{c}\text { Tainfal } \\
\mathbf{1} / \mathbf{m m}\end{array}$ & $\begin{array}{c}\text { Total } \\
\text { sewage } \\
\text { discharge/1 } \\
\mathbf{0 0} \text { million } \\
\text { tons }\end{array}$ & $\begin{array}{c}\text { Total } \\
\text { sewage } \\
\text { treatment/1 } \\
\mathbf{0 0} \mathbf{m i l l i o n} \\
\text { tons }\end{array}$ \\
\hline 1 & Beijing & Water source type & 165 & 182 & 590 & 20.4 & 19 \\
\hline
\end{tabular}




\begin{tabular}{|c|c|c|c|c|c|c|c|}
\hline 2 & Shanghai & $\begin{array}{c}\text { Water quality } \\
\text { type }\end{array}$ & 199 & 313 & 1389.2 & 22.4 & 21.5 \\
\hline 3 & Guangzhou & Water source type & 488 & 438 & 1820.7 & 23.2 & -- \\
\hline 4 & Shenzhen & Water source type & 198 & 423.3 & 1918.2 & 14.2 & -- \\
\hline 5 & Chengdu & $\begin{array}{l}\text { Water quality } \\
\text { type }\end{array}$ & 877 & 343 & 1434.2 & 12.4 & 12 \\
\hline 6 & Hangzhou & $\begin{array}{c}\text { Water pollution } \\
\text { and water-logging } \\
\text { risk type }\end{array}$ & 1815.8 & 298.9 & 1823.5 & 26.3 & -- \\
\hline 7 & Wuhan & Water source type & 317.3 & 326.9 & 1095.1 & 31.2 & -- \\
\hline 8 & Tianjin & Water source type & 51.8 & 183 & 436.2 & 8 & 4.9 \\
\hline 9 & Nanjing & $\begin{array}{c}\text { Water quality } \\
\text { type }\end{array}$ & 560.3 & 488.6 & 1443.3 & 35.3 & -- \\
\hline 10 & Chongqing & $\begin{array}{l}\text { Water pollution } \\
\text { and water-logging } \\
\text { risk type }\end{array}$ & 1690 & 249 & 1443.3 & 66.1 & -- \\
\hline 11 & Xi'an & Water source type & 219 & 196.3 & 538 & 8.3 & -- \\
\hline 12 & Changsha & $\begin{array}{l}\text { Water quality } \\
\text { type }\end{array}$ & 606.8 & 439.7 & 1296.5 & 31.4 & -- \\
\hline 13 & Qingdao & Water source type & 170.5 & 99.3 & 741.6 & 8 & -- \\
\hline 14 & Shenyang & Water source type & 158.7 & 328 & 444.9 & 23.2 & -- \\
\hline 15 & Suzhou & Water source type & 273 & 626.6 & 1117.7 & 13.5 & -- \\
\hline 16 & Zhengzhou & Water source type & 71.8 & 204.2 & 559.3 & 8.4 & 6.8 \\
\hline 17 & Dongguan & Water source type & 284.7 & 213.2 & 1857.1 & 12 & -- \\
\hline 18 & Hefei & Water source type & 262.8 & 377 & 696.6 & 26.2 & -- \\
\hline 19 & Foshan & $\begin{array}{c}\text { Water quality } \\
\text { type }\end{array}$ & 511 & 388 & 1991.1 & 11.3 & -- \\
\hline 20 & Ningbo & $\begin{array}{c}\text { Water pollution } \\
\text { and water-logging } \\
\text { risk type }\end{array}$ & 1430.8 & 239 & 2103 & 17.4 & -- \\
\hline 21 & Kunming & $\begin{array}{c}\text { Water pollution } \\
\text { and water-logging } \\
\text { risk type }\end{array}$ & 1536 & 280 & 1000 & 15.9 & 8.7 \\
\hline 22 & Fuzhou & $\begin{array}{c}\text { Water quality } \\
\text { type }\end{array}$ & 934.9 & 429.2 & 1548.2 & 4.2 & 3.6 \\
\hline 23 & Wuxi & $\begin{array}{c}\text { Water quality } \\
\text { type }\end{array}$ & 575 & 298 & 1100 & 6.6 & 5.2 \\
\hline 24 & Xiamen & Water source type & 219.6 & 156.8 & 1290.2 & 1.3 & -- \\
\hline 25 & Jinan & Water source type & 218.4 & 174.3 & 810.9 & 2.9 & -- \\
\hline 26 & Dalian & Water source type & 412 & 271.6 & 651.4 & 16.1 & -- \\
\hline 27 & Harbin & Water source type & 102.8 & -- & -- & 3 & -- \\
\hline 28 & Wenzhou & $\begin{array}{c}\text { Water pollution } \\
\text { and water-logging } \\
\text { risk type }\end{array}$ & 1381.4 & 192.6 & 1912.3 & 15.2 & -- \\
\hline 29 & Shijiazhuang & Water source type & 178 & 293 & 554.8 & 25.9 & -- \\
\hline 30 & Quanzhou & $\begin{array}{c}\text { Water pollution } \\
\text { and water-logging } \\
\text { risk type }\end{array}$ & 1747 & 61.8 & -- & 4.3 & -- \\
\hline 31 & Nanning & $\begin{array}{l}\text { Water pollution } \\
\text { and water-logging } \\
\text { risk type }\end{array}$ & 2041.4 & 599 & 1339 & 6.4 & -- \\
\hline 32 & Changchun & Water source type & 221.9 & 311.1 & 451.8 & 2.9 & -- \\
\hline 33 & Nanchang & $\begin{array}{c}\text { Water pollution } \\
\text { and water-logging } \\
\text { risk type }\end{array}$ & 1318.9 & 573 & 1368.4 & 27.3 & -- \\
\hline 34 & Guiyang & $\begin{array}{l}\text { Water quality } \\
\text { type }\end{array}$ & 984.9 & 228.7 & 1132.6 & 9.1 & -- \\
\hline 35 & Jinhua & $\begin{array}{c}\text { Water pollution } \\
\text { and water-logging } \\
\text { risk type }\end{array}$ & 2476.3 & 178.1 & 1985.4 & 8.5 & -- \\
\hline
\end{tabular}




\begin{tabular}{|c|c|c|c|c|c|c|c|}
\hline 36 & Changzhou & $\begin{array}{c}\text { Water quality } \\
\text { type }\end{array}$ & 513.5 & 548.2 & 1243.8 & 21.9 & -- \\
\hline 37 & Huizhou & $\begin{array}{c}\text { Water pollution } \\
\text { and water-logging } \\
\text { risk type }\end{array}$ & 3163.1 & 539.5 & 1897 & 6.2 & -- \\
\hline 38 & Jiaxing & $\begin{array}{c}\text { Water quality } \\
\text { type }\end{array}$ & 697.2 & 374.8 & 1505.3 & 15.3 & -- \\
\hline 39 & Nantong & $\begin{array}{c}\text { Water quality } \\
\text { type }\end{array}$ & 623.4 & 560.6 & 1088.5 & 34.8 & -- \\
\hline 40 & Xuzhou & - & -- & -- & 858.3 & -- & -- \\
\hline 41 & Taiyuan & Water source type & 123.4 & 154.5 & 481.7 & 2.2 & 1.5 \\
\hline 42 & Zhuhai & $\begin{array}{c}\text { Water quality } \\
\text { type }\end{array}$ & 921.3 & 306 & 2114 & 5.3 & -- \\
\hline 43 & Zhongshan & $\begin{array}{c}\text { Water quality } \\
\text { type }\end{array}$ & 525.4 & 575 & 1762.9 & 16.5 & -- \\
\hline 44 & Baoding & Water source type & 189 & 9.4 & 99 & 0.8 & -- \\
\hline 45 & Lanzhou & $\begin{array}{c}\text { Water quality } \\
\text { type }\end{array}$ & 751.1 & 450.2 & 251.4 & 5.6 & -- \\
\hline 46 & Taizhou & $\begin{array}{c}\text { Water pollution } \\
\text { and water-logging } \\
\text { risk type }\end{array}$ & 1648 & 271 & 1765.7 & 14.1 & -- \\
\hline 47 & Shaoxing & $\begin{array}{l}\text { Water pollution } \\
\text { and water-logging } \\
\text { risk type }\end{array}$ & 1461 & 398.6 & 1566.9 & 17.1 & -- \\
\hline 48 & Yantai & Water source type & 106 & 129.8 & 446.6 & 7.8 & -- \\
\hline 49 & Langfang & Water source type & 128.7 & 19.5 & 33.4 & 0.8 & -- \\
\hline
\end{tabular}

\section{Analysis and solutions of problems faced by sponge city construction}

After clarifying the types of sponge cities in my country's important cities, the regional adaptive construction plans of sponge cities are summarized for the different water problems of the three types of cities.

\subsection{Analysis and solutions to the problems of water-sourced water-scarce cities}

\subsubsection{Insufficient rainwater recycling rate}

\subsubsection{Reservoir}

The reservoir has the function of rainwater storage and can also reduce peak flow. It is suitable for communities and building green spaces that require rainwater recovery. Rainwater can be reused for green irrigation and pavement washing, saving land, and rainwater pipes are easy to access, but the construction cost is high.

\subsubsection{Rainwater tank}

The rainwater tank is a closed simple rainwater collection and utilization facility on the ground and underground, which is suitable for rainwater collection and utilization on the roof of a single building. Its storage volume is small and rainwater purification capacity is limited.

\subsubsection{Rainwater garden}

The rain garden is a shallow recessed green space that gathers and absorbs rainwater from the roof or the ground. It is an ecologically sustainable rainwater utilization facility that allows rainwater to infiltrate the soil through plants and sand to conserve groundwater; or to replenish urban water such as landscapes and toilets.

\subsubsection{Treatment of curb openings}

The curb opening is to introduce the road runoff rainwater into the biological retention facility for purification and storage.

\subsubsection{Insufficient wastewater recycling rate}

\subsubsection{Planting ditches}

Grass-planting ditch can collect, transport, purify and discharge runoff rainwater, and wet grass-planting ditch can also improve the effect of runoff pollution control.

\subsubsection{Initial rainwater abandonment facilities}

The initial rainwater abandonment facility discards the initial rainfall runoff that contains high concentrations of pollutants, reducing the difficulty of subsequent treatment of rainwater. Discarded rainwater is discharged into the municipal sewage pipe network, and is treated by the sewage treatment plant. It is suitable for roof rainwater down-pipes, runoff rainwater centralized inlets, etc. 


\subsection{Analysis and solutions to the problems of water-deficient cities}

\subsubsection{Serious water pollution}

\subsubsection{Sunken green space}

In a narrow sense, sunken green space refers to green space within $200 \mathrm{~mm}$ below the surrounding paved ground or road. In a broad sense, sunken green space refers to green space that has a certain storage capacity and can be used to purify runoff rainwater, including biological retention ponds, infiltration ponds, wet ponds, Rainwater wetlands, regulating ponds, etc.

\subsubsection{Biological retention facilities}

66Biological retention facilities as shown in Figure 3 are located in low-lying areas, and use plants, soil and microbial systems to store and infiltrate and purify runoff rainwater. They are suitable for buildings in communities, roads and green spaces around parking lots, and urban road green belts.

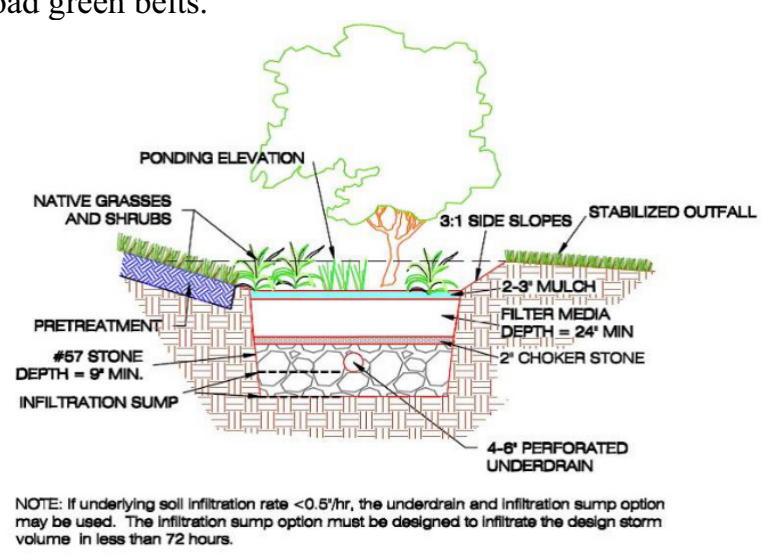

Figure 3.The structure of an enhanced bio-retention design

\subsubsection{Rain and sewage separation system}

For communities with a large area, the transformation method of "retaining the confluence pipe as a sewage pipe and building a new rainwater pipe" is adopted, because the sewage collection system is more complicated and the amount of excavation is large.

\subsubsection{Rainwater collection system}

For municipal roads, the transformation method of "retaining the confluence pipe as rainwater pipes and constructing new sewage pipes" is adopted, because the rainwater pipes are large in size and the gutter can be moved to the green belt[12].

\subsubsection{Matrix ratio of permeable layer and water permeability of underlying surface}

The permeable layer structure adopts multi-layer design with better filtering effect and larger rainwater storage capacity, such as (permeable brick + sand + gravel). Among them, the (zeolite + vermiculite + ceramsite) mixed matrix has the fastest penetration rate, which can bear the rainwater penetration of 11-29 times more than its own area[13].

\subsubsection{Insufficient green area}

\subsubsection{Plant buffer zone}

The vegetation buffer zone slows down the surface runoff velocity through interception and soil infiltration, and removes some pollutants, with a slope of $2 \%-6 \%$. It is suitable for roads and other impervious surfaces, can be used as pre-treatment facilities for biological retention facilities, and can also be used as a waterfront green belt in urban water systems.

\subsubsection{Green roof}

Green roofs are divided into simple and garden styles as shown in Figure 9: the substrate depth of the simple style is no more than $150 \mathrm{~mm}$, and the substrate depth of the garden style can exceed $600 \mathrm{~mm}$ when planting trees. It effectively reduces the total amount of roof runoff and runoff pollution load, saves energy and reduces emissions, and has strict requirements on roof load, waterproofing, slope, and space conditions.

\subsection{Analysis and solutions of urban problems with water pollution and water-logging risk}

\subsubsection{Excessive hardened area}

\subsubsection{Permeable bricks, grass-inlaid bricks}

Permeable bricks are suitable for squares, parking lots, sidewalks, and roads with small traffic and load, such as building and community roads, municipal roads and nonmotorized roads.

\subsubsection{Excessive rainfall}

\subsubsection{Wet pond}

The wet pond has the functions of rainwater regulation, storage and purification, and can be designed as a multifunctional water regulation and storage body in combination with green spaces and open spaces: it can play normal landscape, leisure and entertainment functions at ordinary times, and it can play a regulation and storage function during heavy rains to realize multifunctional utilization of land resources.

\subsubsection{2Regulation pond}

The regulating pond can reduce the peak flow and consists of water inlet, regulating area, outlet, slope protection and embankment. Make it permeable through reasonable design, supplement groundwater and purify rainwater.

\subsubsection{Backward drainage network}

Aiming at the problems of aging sewage pipe network, too small diameter, incorrect elevation and siltation of 
upstream and downstream sewage, formulate a transformation plan to speed up the construction of sewage pipe network, expand the coverage of sewage pipe network, and increase the sewage collection rate. During the construction of the sewage pipe network, a strict reward and punishment system will be implemented and relevant standards will be refined.

\subsubsection{Rainwater wetland}

Rainwater wetlands use aquatic plants to purify rainwater, which is an efficient runoff pollution control facility as shown in Figure 4. Rainwater wetlands are often built together with wet ponds, consisting of water inlets, front ponds, swamp areas, outlet pools, overflow and outflow outlets, slope protection and revetment, maintenance channels, etc.

\subsubsection{Industrial, agricultural and domestic pollution}

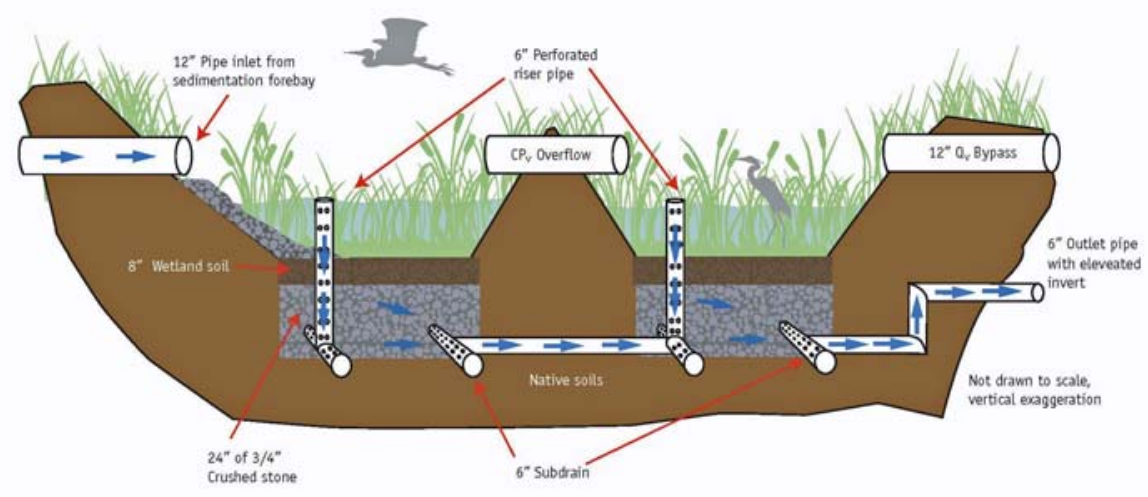

Figure 4. The structure of rainwater wetland

\subsubsection{Seepage well}

Infiltration wells refer to facilities for rainwater infiltration through well walls and bottoms, and are suitable for buildings, roads and green spaces around parking lots in communities.

\section{Conclusions}

This article divides important cities across the country into water-source-type water shortages, water-qualitytype water shortages, and water pollution and waterlogging risk cities, in order to explore regional construction programs in a targeted manner.

\section{References}

1. Zhang Yingxia. Overview of the development of low-impact development technology in the United States. City\&House.2015(9):23-26.

2. Wang Li. Water resources protection and development in the construction of a conservationoriented society. Science and Technology and Enterprise. 2013(15): 139

3. Huang Changwu. Current status of water pollution in my country. Environmental Science Trends. 1983(9): 4

4. Ji Pengcheng. The status quo and suggestions of my country's urban water price reform. Macroeconomic management. 2009(4):49

5. Ministry of Water Resources of the People's Republic of China. China Water Resources Bulletin. 2019:1
6. Wang Minghua. Which countries in the world have the most water shortage. China Academic Journal Electronic Publishing House. 1994-2020:49.

7. $\mathrm{Li}$ Gaoshe. Research on the division of the boundary between semi-humid and semi-arid areas of the Loess Plateau. Geographic Collection (21). Science Press. 1990:111-124.

8. Tang Bo. Hu Huanyong and the mysterious "Hu Huanyong Line". At that time Mingyue: 113

9. Peng Yuejin. Fuzzy multi-factor multi-level comprehensive evaluation method for water shortage degree and type of water shortage cities in the country. Water Resources Planning. 1996(4): 22-24

10. Research Institute of New First-tier Cities. Ranking List of Urban Business Charm. China Business News. 2019

11. Urban Water Affairs Bureau. Water Resources Bulletin. Water Affairs Bureau official website. 2019

12. Zhong Jiang. Discussion on the measures and application of rain and sewage diversion transformation of urban drainage system. Engineering Technology. 2014(11):41

13. Wang Xin. Optimization of the underlying surface of sponge city and its effect on simulated rainwater treatment. Journal of Environmental Engineering. 2018.Vol.12.No.7:1953. 